\title{
A Spatiotemporal Study of Unfavorable Balance of Inbound-Outbound Travelers in Taiwan
}

\author{
Yin-Hao Kuo ${ }^{1,2}$, Yu-Chan Tsai ${ }^{2}$, Ting-An Chen ${ }^{2}$ and Wen-Ting Lin ${ }^{2}$ \\ ${ }^{1}$ National Taiwan University of Science and Technology, Taipei, Taiwan \\ ${ }^{2}$ Taipei City University of Science and Technology, Taipei, Taiwan
}

\begin{abstract}
Based on the official data, the monthly inbound and outbound tourists from 2005 to 2015 with different genders of top 10 main markets in Taiwan, were collected and analyzed by this study to demonstrate and explore the static and dynamic patterns behind these historical records.This study, not only discussed the static phenomenon that deficit or surplus of travelers occurred in each market, but monitored its dynamic variation as well. Statistical procedures including correlation analysis, K-mean clustering, MANOVA analysis, and MDS, were respectively adopted to discover the correlative relation among each different spatiotemporal market, determine each observation into proper group, testify the hypotheses of heterogeneous, and down-level the spatial complexity from high-dimension to 2-dimension in order to better interpret the patterns revealed behind the original space.
\end{abstract}

Keywords: Tourism deficit, Tourism surplus, Inbound-Outbound Travelers

\section{Introduction}

As being a demanding-driven and service-oriented industry that had been experienced rapid growth and innovation during decades, tourism constantly plays a key role in the growth of economy through employment, foreign exchange earnings, investment, and regional development.

According to the Tourism Highlights 2016 Edition which was published by UNWTO, The world Tourism Organization, 8 points can be concluded as follow.

(1) Since an ever-increasing number of destinations worldwide have opened up and invested in this industry, tourism plays an key driver of socio-economic progress through the creation of jobs and enterprises, export revenues, and infrastructure development.

(2) Tourism, over the past six decades, has experienced continued expansion and diversification to become one of the largest and fastest-growing economic sectors in the world. Many new traveling destinations have emerged in addition to the traditional favorites of Europe and North America.

(3) Despite experienced occasional shocks, tourism has boasted virtually uninterrupted growth over time, demonstrating the sector's strength and resilience.

(4) International tourist arrivals have increased from 25 million globally in 1950 to 278 million in 1980, 674 million in 2000, and 1186 million in 2015.

(5) International tourism receipts earned by destinations worldwide have surged from US\$ 2 billion in 1950 to US\$ 104 billion in 1980, US\$ 495 billion in 2000, and US\$ 1260 billion in 2015.

(6) In addition to receipts earned in destinations, international tourism generated US\$ 211 billion in exports through international passenger transport services rendered to non-residents in 2015, bringing the total value of tourism exports up to US\$1.5 trillion, or US\$ 4 billion a day on average.

(7) International tourism now represents 7\% of the world's exports in goods and services, up from 6\% in 2014, as tourism has grown faster than world trade over the past four years.

(8) Tourism has become a major category of international trade in services. As a worldwide export category, tourism ranks third after fuels and chemicals and ahead of food and automotive products. In many developing countries, tourism ranks as the first export sector. 
Arrivals, receipts, and associated weights cross regions of international tourism in 2015 is shown in Fig. 1, and the amounts of international tourism arrivals and receipts for past 2 decades is offered in Fig. 2. The International tourist arrivals and tourism receipts 2016 are given in table 1 and 2 .

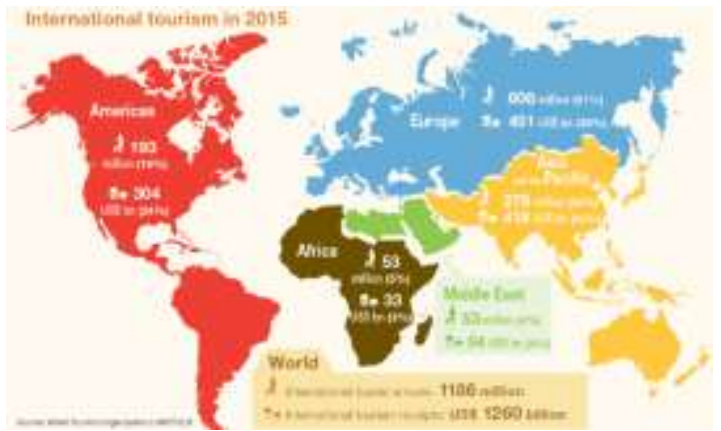

Fig. 1: International tourism overview in 2015.

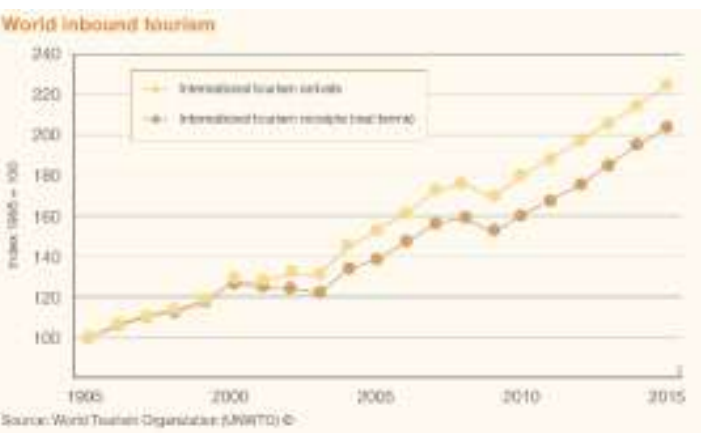

Fig. 2: World tourism arrivals/receipts

TABLE 1: The International tourist arrivals

\begin{tabular}{|c|c|c|c|c|c|c|c|c|c|c|c|c|}
\hline & \multicolumn{6}{|c|}{$\begin{array}{l}\text { International tourist arrivals } \\
\text { (million) }\end{array}$} & \multicolumn{2}{|r|}{$\begin{array}{c}\text { Market } \\
\text { share (\%) }\end{array}$} & \multicolumn{3}{|c|}{$\begin{array}{c}\text { Change } \\
(\%)\end{array}$} & \multirow{2}{*}{$\begin{array}{l}\begin{array}{l}\text { Average } \\
\text { a year }(\%)\end{array} \\
2005-15\end{array}$} \\
\hline & 1990 & 1995 & 2000 & 2005 & 2010 & 2014 & $2015^{*}$ & $2015^{*}$ & $13 / 12$ & $14 / 13$ & $15 * / 14$ & \\
\hline World & 435 & 527 & 674 & 809 & 950 & 1134 & 1186 & 100.0 & 4.6 & 4.2 & 4.6 & 3.9 \\
\hline Advanced economies* & 299 & 339 & 424 & 470 & 516 & 622 & 653 & 55.0 & 4.6 & 5.7 & 5.0 & 3.3 \\
\hline Emerging economies* & 136 & 188 & 250 & 339 & 434 & 512 & 533 & 45.0 & 4.6 & 2.4 & 4.1 & 4.6 \\
\hline \multicolumn{13}{|l|}{ By UNWTO regions: } \\
\hline Europe & 261.5 & 304.5 & 386.6 & 453.2 & 489.4 & 580.2 & 607.7 & 51.2 & 4.8 & 2.3 & 4.7 & 3.0 \\
\hline Northern Europe & 28.7 & 36.4 & 44.8 & 59.9 & 62.8 & 70.8 & 75.9 & 6.4 & 2.4 & 5.3 & 7.3 & 2.4 \\
\hline Western Europe & 108.6 & 112.2 & 139.7 & 141.7 & 154.4 & 174.4 & 180.0 & 15.2 & 2.8 & 2.1 & 3.2 & 2.4 \\
\hline Central/Eastern Europe & 33.9 & 57.9 & 69.6 & 95.3 & 98.9 & 120.2 & 126.6 & 10.7 & 7.7 & -6.2 & 5.3 & 2.9 \\
\hline Southern/Medit. Europe & 90.3 & 98.0 & 132.6 & 156.4 & 173.3 & 214.8 & 225.2 & 19.0 & 5.6 & 6.9 & 4.8 & 3.7 \\
\hline -of which EU-28 & 230.1 & 268.0 & 330.5 & 367.9 & 384.3 & 454.1 & 478.4 & 40.3 & 3.9 & 4.8 & 5.4 & 2.7 \\
\hline Asia and the Pacific & 55.9 & 82.1 & 110.4 & 154.0 & 205.5 & 264.3 & 279.2 & 23 & 6.9 & 5.7 & 5.6 & 6.1 \\
\hline North-East Asia & 26.4 & 41.3 & 58.3 & 85.9 & 111.5 & 136.3 & 142.1 & 12.0 & 3.4 & 7.3 & 4.3 & 5.2 \\
\hline South-East Asia & 21.2 & 28.5 & 36.3 & 49.0 & 70.5 & 97.3 & 104.6 & 8.8 & 11.3 & 3.0 & 7.6 & 7.9 \\
\hline Oceania & 5.2 & 8.1 & 9.6 & 10.9 & 11.4 & 13.3 & 14.2 & 1.2 & 4.6 & 6.1 & 7.4 & 2.7 \\
\hline South Asia & 3.2 & 4.2 & 6.1 & 8.2 & 12.1 & 17.5 & 18.3 & 1.5 & 12.1 & 9.6 & 4.4 & 8.4 \\
\hline Americas & 92.8 & 108.9 & 128.2 & 133.3 & 150.2 & 181.9 & 192.6 & 16.2 & 3.0 & 8.5 & 5.9 & 3.7 \\
\hline North America & 71.8 & 80.5 & 91.5 & 89.9 & 99.5 & 120.9 & 127.6 & 10.8 & 3.6 & 9.7 & 5.5 & 3.6 \\
\hline Caribbean & 11.4 & 14.0 & 17.1 & 18.8 & 19.5 & 22.3 & 23.9 & 2.0 & 2.7 & 5.5 & 7.4 & 2.4 \\
\hline Central America & 1.9 & 2.6 & 4.3 & 6.3 & 7.9 & 9.6 & 10.3 & 0.9 & 2.6 & 5.6 & 7.1 & 5.0 \\
\hline South America & 7.7 & 11.7 & 15.3 & 18.3 & 23.2 & 29.1 & 30.8 & 2.6 & 1.4 & 7.1 & 5.8 & 5.3 \\
\hline Africa & 14.8 & 18.7 & 26.2 & 34.8 & 50.4 & 55.3 & 53.5 & 4.5 & 4.4 & 1.1 & -3.3 & 4.4 \\
\hline North & 8.4 & 7.3 & 10.2 & 13.9 & 19.7 & 20.4 & 18.0 & 1.5 & 5.8 & -1.4 & -11.7 & 2.6 \\
\hline Subsaharan Africa & 6.4 & 11.5 & 16.0 & 20.9 & 30.7 & 34.9 & 35.4 & 3.0 & 3.6 & 2.7 & 1.6 & 5.4 \\
\hline Middle East & 9.6 & 12.7 & 22.4 & 33.7 & 54.7 & 52.4 & 53.3 & 4.5 & -2.9 & 6.7 & 1.7 & 4.7 \\
\hline
\end{tabular}

Source:UNWTO (data was collected by UNWTO, July 2016)

* Classification based on the IMF

TABLE II: The International tourism receipts

\begin{tabular}{|c|c|c|c|c|c|c|c|c|c|c|}
\hline & \multicolumn{4}{|c|}{ International tourist receipts } & \multirow{2}{*}{$\begin{array}{c}\text { Market } \\
\text { share }(\%)\end{array}$} & \multicolumn{3}{|c|}{ Receipts (US\$) } & \multicolumn{2}{|c|}{ Receipts (euro) } \\
\hline & \multicolumn{2}{|c|}{ Local currencies, cor } & \multicolumn{2}{|c|}{ prices $(\%$ change $)$} & & (bill & ons) & per arrival & (billions) & per arrival \\
\hline & $12 / 11$ & $13 / 12$ & $14 / 13$ & $15 * / 14$ & $2015^{*}$ & 2014 & $2015^{*}$ & $2015^{*}$ & $20142015 *$ & $2015^{*}$ \\
\hline World & 4.3 & 5.9 & 5.1 & 4.4 & 100.0 & 1,309 & 1,260 & 1,060 & 9861,136 & 960 \\
\hline Advanced economies* & 3.6 & 6.1 & 4.9 & 3.1 & 61.5 & 829 & 774 & 1,190 & $624 \quad 698$ & 1,070 \\
\hline Emerging economies* & 5.4 & 5.5 & 5.5 & 6.7 & 38.5 & 481 & 486 & 910 & 362 & 820 \\
\hline \multicolumn{11}{|l|}{ By UNWTO regions: } \\
\hline Europe & 1.8 & 4.1 & 4.3 & 3.0 & 35.8 & 513.5 & 450.7 & 740 & 386.6406 .2 & 670 \\
\hline Northern Europe & 3.3 & 7.5 & 6.4 & 7.6 & 6.2 & 82.5 & 78.4 & 1,030 & $62.1 \quad 70.7$ & 930 \\
\hline Western Europe & 2.7 & 2.2 & 3.3 & 0.2 & 11.6 & 173.7 & 146.4 & 810 & 130.7131 .9 & 730 \\
\hline Central/Eastern Europe & 4.3 & 3.5 & -0.9 & -0.4 & 4.0 & 58.2 & 50.1 & 400 & $43.8 \quad 45.2$ & 360 \\
\hline Southern/Medit. Europe & -0.3 & 4.8 & 6.1 & 5.0 & 14.0 & 199.2 & 175.8 & 780 & 149.9158 .4 & 700 \\
\hline -of which EU-28 & 1.5 & 3.8 & 4.6 & 3.4 & 29.6 & 427.3 & 373.4 & 780 & 321.6336 .5 & 700 \\
\hline
\end{tabular}




\begin{tabular}{|c|c|c|c|c|c|c|c|c|c|c|c|}
\hline & \multirow{2}{*}{$\begin{array}{l}\text { Int } \\
\text { Local curre }\end{array}$} & \multicolumn{3}{|c|}{ International tourist receipts } & \multirow{2}{*}{$\begin{array}{c}\text { Market } \\
\text { share }(\%)\end{array}$} & \multicolumn{3}{|c|}{ Receipts (US\$) } & \multicolumn{3}{|c|}{ Receipts (euro) } \\
\hline & & es, cons & $\mathrm{t}$ prices & change) & & \multicolumn{2}{|c|}{ (billions) } & \multirow{2}{*}{$\frac{\text { per arrival }}{2015^{*}}$} & \multicolumn{2}{|c|}{ (billions) } & \multirow{2}{*}{ * per arrival } \\
\hline & $12 / 11$ & $13 / 12$ & $14 / 13$ & $15 * / 14$ & $2015 *$ & 2014 & $2015^{*}$ & & 2014 & $2015^{*}$ & \\
\hline Asia and the Pacific & 7.6 & 9.3 & 5.3 & 4.0 & 33.2 & 420.1 & 418.3 & 1,500 & 316.2 & 377.0 & 1,350 \\
\hline North-East Asia & 8.6 & 10.4 & 6.1 & 0.8 & 18.8 & 238.0 & 236.7 & 1,670 & 179.1 & 213.3 & 1,500 \\
\hline South-East Asia & 10.9 & 10.6 & 2.0 & 7.8 & 8.6 & 108.1 & 108.3 & 1,030 & 81.4 & 97.6 & 930 \\
\hline Oceania & -1.8 & 2.0 & 7.2 & 9.9 & 3.3 & 44.6 & 41.9 & 2,940 & 33.6 & 37.8 & 2,650 \\
\hline South Asia & 4.9 & 8.7 & 8.5 & 7.1 & 2.5 & 29.4 & 31.4 & 1,720 & 22.1 & 28.3 & 1,550 \\
\hline Americas & 4.7 & 6.7 & 6.4 & 7.8 & 24.1 & 288.0 & 303.7 & 1,580 & 216.8 & 273.7 & 1,420 \\
\hline North America & 5.0 & 7.4 & 6.6 & 8.2 & 18.9 & 225.0 & 238.5 & 1,870 & 169.3 & 214.9 & 1,680 \\
\hline Caribbean & 1.2 & 3.7 & 4.8 & 5.8 & 2.2 & 26.7 & 28.1 & 1,170 & 20.1 & 25.3 & 1,060 \\
\hline Central America & 7.8 & 7.2 & 6.2 & 7.3 & 0.9 & 10.6 & 11.5 & 1,120 & 8.0 & 10.4 & 1,010 \\
\hline South America & 4.8 & 3.4 & 6.2 & 7.0 & 2.0 & 25.7 & 25.6 & 830 & 19.3 & 23.0 & 750 \\
\hline Africa & 6.2 & 2.4 & 2.4 & 2.4 & 2.6 & 36.1 & 33.1 & 620 & 27.2 & 29.8 & 560 \\
\hline North Africa & 8.2 & -2.1 & 5.2 & -9.8 & 0.7 & 10.6 & 8.6 & 470 & 8.0 & 7.7 & 430 \\
\hline Subsaharan Africa & 5.5 & 4.2 & 1.4 & 7.5 & 1.9 & 25.5 & 24.5 & 690 & 19.2 & 22.1 & 620 \\
\hline Middle East & 1.8 & -4.6 & 7.4 & 4.3 & 4.3 & 51.6 & 54.4 & 1,020 & 38.8 & 49.0 & 920 \\
\hline
\end{tabular}

Source:UNWTO (data was collected by UNWTO, July 2016)

* Classification based on the IMF

By collecting the amount of monthly inbound and outbound travelers from 2005 to 2015 with different genders of top 13 main markets, including Mainland China, Hong Kong (with Macau), Japan, U.S.A, Malaysia, Singapore, Korea, Indonesia, Philippines, Vietnam, Austria, Canada and Thailand as well, this study not only analyzed and explored the static and dynamic patterns in order to capture and track on the spatiotemporal composition and variation behind these historical records, but discussed the static phenomenon that deficit or surplus of travelers occurred in each market as well.

The purpose of this article, unlike models construction which often discussed in the tourism demand field, is to explore, compare, cluster, and scale among the 13 top inbound-outbound markets not only in a spatial but a temporal viewpoint with respective to different genders and associated ratios. The rest of this paper is organized as follows. Section 2 presents a review of the relevant literature and describes the descriptive statistics of collected data. Section 3 outlines the methodology of the whole analysis process. Section 4 describes the empirical finding, while discussing and conclusions are drawn at Section 5.

\section{Literature Review}

When ranking the world's top international tourism destinations, it is preferable to take more than a single indicator into account (UWTO, 2016). Ranked according to the two key inbound tourism indicators international tourist arrivals and international tourism receipts. Table 3 lists the top 10 countries of international arrivals and table 4 gives the top 10 international tourism receipts around the world. For comparison purpose, the data of Taiwan is also demonstrated in each table.

TABLE III: Top 10 International tourist arrivals countries 2016

\begin{tabular}{|c|c|c|c|c|c|}
\hline \multirow{2}{*}{ Rank } & \multirow{2}{*}{ Country } & \multicolumn{2}{|c|}{ (millions) } & \multicolumn{2}{|c|}{ Change (\%) } \\
\hline & & 2014 & $2015^{*}$ & $14 / 13$ & $15 * / 14$ \\
\hline 1 & France & 83.7 & 84.5 & 0.1 & 0.9 \\
\hline 2 & United States & 75.0 & 77.5 & 7.2 & 3.3 \\
\hline 3 & Spain & 64.9 & 68.5 & 7.0 & 5.0 \\
\hline 4 & China & 55.6 & 56.9 & -0.1 & 2.3 \\
\hline 5 & Italy & 48.6 & 50.7 & 1.8 & 4.4 \\
\hline 6 & Turkey & 39.8 & 39.5 & 5.3 & -0.8 \\
\hline 7 & Germany & 33.0 & 35.0 & 4.6 & 6.0 \\
\hline 8 & United Kingdom & 32.6 & 34.4 & 5.0 & 5.6 \\
\hline 9 & Mexico & 29.3 & 32.1 & 21.5 & 9.4 \\
\hline \multirow[t]{2}{*}{10} & Russian Federation & 29.8 & 31.3 & 5.3 & 5.0 \\
\hline & Taiwan & 9.9 & 10.4 & 23.6 & 5.3 \\
\hline
\end{tabular}


TABLE IV: Top 10 international tourism receipts countries 2016

\begin{tabular}{|c|c|c|c|c|c|c|c|}
\hline \multirow{3}{*}{ Rank } & \multirow{3}{*}{ Country } & \multicolumn{4}{|c|}{ US\$ } & \multirow{2}{*}{\multicolumn{2}{|c|}{$\begin{array}{c}\text { Local currenies } \\
\text { Change }(\%) \\
\end{array}$}} \\
\hline & & \multicolumn{2}{|c|}{ (billions) } & \multicolumn{2}{|c|}{ Change $(\%)$} & & \\
\hline & & 2014 & $2015^{*}$ & $14 / 13$ & $15 * / 14$ & $14 / 13$ & $15 * / 14$ \\
\hline 1 & United States & 191.3 & 204.5 & 7.8 & 6.9 & 7.8 & 6.9 \\
\hline 2 & China & 105.4 & 114.1 & $\mathrm{n} / \mathrm{a}$ & 8.3 & $\mathrm{n} / \mathrm{a}$ & 9.8 \\
\hline 3 & Spain & 65.1 & 56.5 & 3.9 & -13.2 & 3.9 & 4.0 \\
\hline 4 & France & 58.1 & 45.9 & 2.8 & -21.0 & 2.8 & -5.4 \\
\hline 5 & United Kingdom & 46.5 & 45.5 & 11.8 & -2.3 & 6.2 & 5.2 \\
\hline 6 & Thailand & 38.4 & 44.6 & -8.0 & 16.0 & -2.7 & 22.0 \\
\hline 7 & Italy & 45.5 & 39.4 & 3.6 & -13.3 & 3.6 & 3.8 \\
\hline 8 & Germany & 43.3 & 36.9 & 4.9 & -14.6 & 4.9 & 1.9 \\
\hline 9 & Hong Kong (China) & 38.4 & 36.2 & -1.4 & -5.8 & -1.5 & -5.8 \\
\hline \multirow[t]{2}{*}{10} & Macao (China) & 42.6 & 31.3 & -1.1 & -26.4 & -1.1 & -26.5 \\
\hline & Taiwan & 14.6 & 14.4 & 0.2 & -0.0 & $\mathrm{n} / \mathrm{a}$ & $\mathrm{n} / \mathrm{a}$ \\
\hline
\end{tabular}

Source:UNWTO (data was collected by UNWTO, July 2016)

Due to the perishable nature of the tourism industry, the need to carry accurate forecasts has become more and more crucial (Chandra \& Meneze, 2001; Law, 2000; Law \& Au, 1999). Meanwhile, no matter in which country or market, since tourism demand is the essential foundation on which all tourism-related business decisions conclusively rest (Song \& Witt, 2006), the forecasting of tourism demand always keep on attracting lots of attentions and interests during last few decades among researchers, practitioners, and policy makers. Just possessed under the command of science and art, the forecasting of tourism demand can be modeled in various ways. They include exponential smoothing (Cho, 2003), ARIMA (Cho, 2003' Chu, 1998; Goh \& Law, 2002; Lim \& McAlee, 2002), vector autoregressive (Song \& Witt, 2006; Wong, Song, \& Chon, 2006), neural network (Chen \& Wang, 2007; Cho, 2003; Law, 2000;Law \& Au, 1999), fuzzy time series (Wang, 2004; Wang \& Hsu, 2008), grey model (Hsu \& Wen, 1998; Wang, 2004), adaptive network-based fuzzy inference system (Chen, Ying, \& Pan, 2010), econometric (Hiemstra \& Wong, 2002; Smeral, Witt, \& Witt, 1992; Song \& Wit, 2000; Witt \& Martin, 1987), regression-base model (Chan, 1993; Crouch, Schultz \& Valerio, 1992; Kulendran \& Witt, 2001), and genetic algorithm (Chen \& Wang, 2007; Hernandez-Lopez \& Caceres-Hernandez, 2007; Hernandez-Lopez, 2004; Hurley, Moutinho \& Witt, 1998).

From the literatures reviewed above, though the tourism demand indeed attracted much attention from researchers to whom devoting themselves kept on pursuing more accurate models in prediction task among markets, the discussion of static composition and dynamic variation researched simultaneously, and the discussion of the static phenomenon that deficit or surplus of travelers occurred in each market seemed attract much less interest for researchers worldwide and Taiwan.

\section{Data and Research Methodology}

\subsection{Data}

As one of the key choice in enjoying a vacation and geographically positioned in the hinge of East Asia, outbound travelling in Taiwan always attracted people when programing and determining their vacations. According to the data collected by authorities, except for USA, there are 9 Asian destinations, including Japan, Hong Kong(with Macau), Mainland China, Korea, Singapore, Thailand, Philippines, Indonesia, and Malaysia as well, preferred by Taiwan visitors among the top 10 outbound destinations in the past decade. Since the ban of forbidding Taiwanese going to China in sightseeing purpose was removed in July 2008, the visitors travelling to Mainland dramatically increased form 188,744 in 2008 to 3,403,920 in 2015, or equivalently, grew 18.04 times. In the same period, the tourist arrivals from China increased from 329,204 in 2008 to 4,184,102, grew 12.71 times.

Based on the official data offered by Tourism Bureau, M.O.T.C., Republic of China, the monthly inbound and outbound travelers of top 10 markets mentioned above, from 2005 to 2015 with different genders, were took into account to analyze in this study. By collecting and calculating monthly inbound and outbound visitors from each market, this study evaluated eight indicators, including male tourists inbound ratio (MTIR), female tourists inbound ratio (FTIR), male tourists outbound ratio (MTOR), female tourists outbound ratio (FTOR), ratio of balance male tourists (RBMT), ratio of balance female tourists (RBFT), ratio of in-out male tourists (RIOMT), 
and ratio of in-out female tourists (RIOFT) as well to capture the gender composition and variation with respect to static and dynamic point of view. The inbound-outbound tourists and weights each year of top 10 markets from 2005 to 2015 are shown in Fig. 3, and the definitions of analyzed indicators are given in table 5. The months collected and analyzed each market are listed in table 6, and the yearly aggregated tourists of every market are illustrated in table 7.

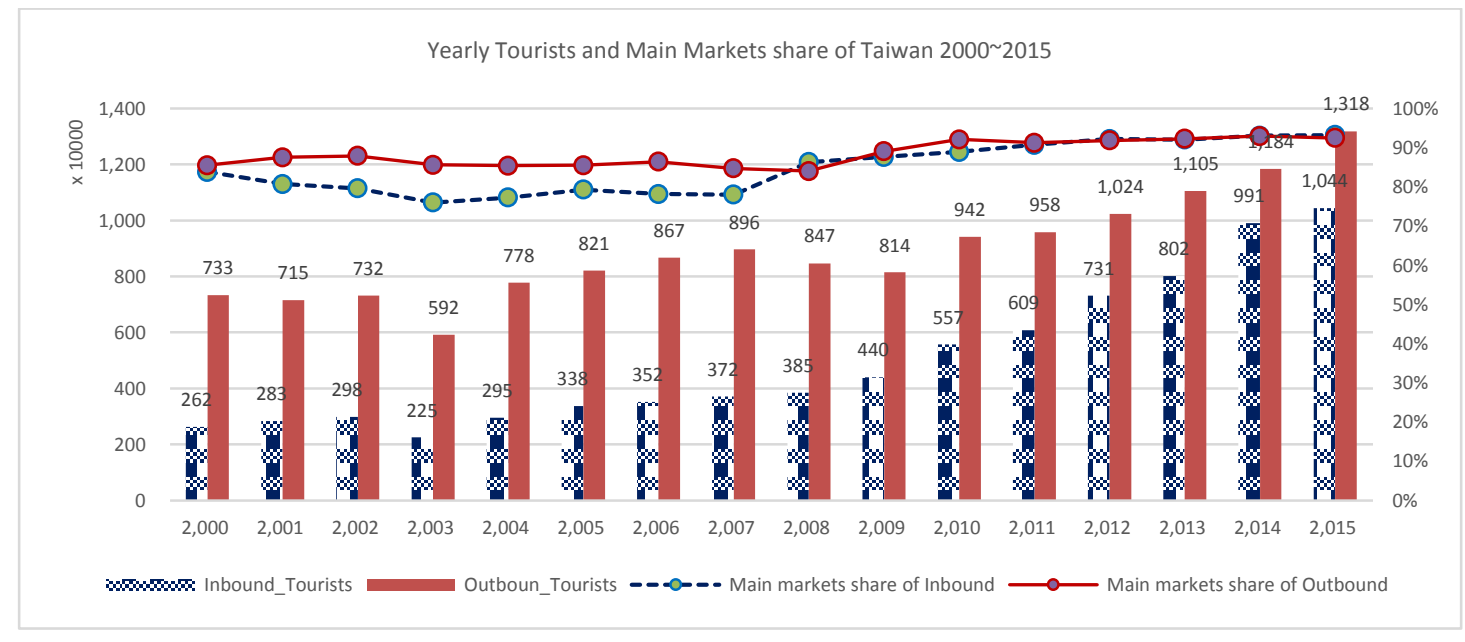

Fig. 3: The inbound-outbound tourists and aggregated weights

TABLE V: Definitions of analyzed indicators

\begin{tabular}{clll}
\hline \hline DV & Indicator & Meaning & Definition \\
\hline 1 & MTIR & Male Tourists Inbound Ratio & Male tourists in/ Total tourist in \\
2 & FTIR & Female Tourists Inbound Ratio & Female tourists in/ Total tourist in \\
3 & MTOR & Male Tourists Outbound Ratio & Male tourists out/ Total tourist out \\
4 & FTOR & $\begin{array}{l}\text { Female Tourists Outbound } \\
\text { Ratio }\end{array}$ & Female tourists out/ Total tourist out \\
5 & RBMT & $\begin{array}{l}\text { Ratio of Balance Male } \\
\text { Tourists }\end{array}$ & Balance* Male / Inbound Male \\
6 & RBFT & $\begin{array}{l}\text { Ratio of Balance Female } \\
\text { Tourists }\end{array}$ & Balance* Female / Inbound Male \\
7 & RIOMT & $\begin{array}{l}\text { Ratio of In-Out Male Tourists } \\
\text { Ratio of In-Out Female } \\
\text { Tourists }\end{array}$ & Inbound Male / Outbound Male \\
& RIOFbound Female / Outbound Female
\end{tabular}

${ }^{*}$ Balance is defined by inbound tourists - outbound tourists

TABLE VI: Months analyzed each market

\begin{tabular}{|c|c|c|c|c|c|c|c|c|c|c|c|c|c|c|c|c|c|c|c|c|c|c|}
\hline Year & & 005 & & 2006 & & 2007 & & 2008 & & 2009 & & 2010 & & 011 & & 2012 & & 2013 & & 2014 & & 015 \\
\hline Market & in & out & in & out & in & out & in & out & in & out & in & out & in & out & in & out & in & out & in & out & in & ou \\
\hline China & - & - & - & - & - & - & 6 & 6 & 12 & 12 & 12 & 12 & 12 & 12 & 12 & 12 & 12 & 12 & 12 & 12 & 12 & 12 \\
\hline HK_MC & 12 & 12 & 12 & 12 & 12 & 12 & 12 & 12 & 12 & 12 & 12 & 12 & 12 & 12 & 12 & 12 & 12 & 12 & 12 & 12 & 12 & \\
\hline Japan & 12 & 12 & 12 & 12 & 12 & 12 & 12 & 12 & 12 & 12 & 12 & 12 & 12 & 12 & 12 & 12 & 12 & 12 & 12 & 12 & 12 & 1 \\
\hline USA & 12 & 12 & 12 & 12 & 12 & 12 & 12 & 12 & 12 & 12 & 12 & 12 & 12 & 12 & 12 & 12 & 12 & 12 & 12 & 12 & 12 & \\
\hline Malaysia & 12 & 12 & 12 & 12 & 12 & 12 & 12 & 12 & 12 & 12 & 12 & 12 & 12 & 12 & 12 & 12 & 12 & 12 & 12 & 12 & 12 & \\
\hline Singapore & 12 & 12 & 12 & 12 & 12 & 12 & 12 & 12 & 12 & 12 & 12 & 12 & 12 & 12 & 12 & 12 & 12 & 12 & 12 & 12 & 12 & 1 \\
\hline Korea & 12 & 12 & 12 & 12 & 12 & 12 & 12 & 12 & 12 & 12 & 12 & 12 & 12 & 12 & 12 & 12 & 12 & 12 & 12 & 12 & 12 & \\
\hline Indonesia & 12 & 12 & 12 & 12 & 12 & 12 & 12 & 12 & 12 & 12 & 12 & 12 & 12 & 12 & 12 & 12 & 12 & 12 & 12 & 12 & 12 & \\
\hline Philippines & 12 & 12 & 12 & 12 & 12 & 12 & 12 & 12 & 12 & 12 & 12 & 12 & 12 & 12 & 12 & 12 & 12 & 12 & 12 & 12 & 12 & 1 \\
\hline Thailand & 12 & 12 & 12 & 12 & 12 & 12 & 12 & 12 & 12 & 12 & 12 & 12 & 12 & 12 & 12 & 12 & 12 & 12 & 12 & 12 & 12 & 1 \\
\hline
\end{tabular}


TABLE VII: Yearly aggregated tourists

\begin{tabular}{|c|c|c|c|c|c|c|c|c|c|c|c|}
\hline Market/Year & 2005 & 2006 & 2007 & 2008 & 2009 & 2010 & 2011 & 2012 & 2013 & 2014 & 2015 \\
\hline \multicolumn{12}{|l|}{ Inbound } \\
\hline China & - & - & - & 225,370 & 972,123 & $1,630,735$ & $1,784,185$ & $2,586,428$ & $2,874,702$ & $3,987,152$ & $4,184,102$ \\
\hline HK_MC & 432,718 & 431,884 & 491,437 & 641,960 & 718,806 & 794,352 & 817,944 & $1,016,356$ & $1,183,341$ & $1,375,770$ & $1,513,597$ \\
\hline Indonesia & 88,464 & 90,870 & 95,572 & 110,420 & 106,612 & 123,834 & 156,281 & 163,598 & 171,299 & 182,704 & 177,743 \\
\hline Japan & 1124,334 & $1,161,489$ & $1,166,380$ & $1,086,691$ & $1,000,661$ & $1,080,153$ & $1,294,424$ & $1,432,315$ & $1,421,550$ & $1,634,790$ & $1,627,229$ \\
\hline Korea & 182,517 & 196,260 & 225,814 & 253,868 & 167,641 & 216,901 & 239,745 & 259,089 & 351,301 & 527,684 & 658,757 \\
\hline Malaysia & 107,549 & 115,202 & 141,308 & 155,783 & 166,987 & 285,734 & 376,340 & 341,032 & 394,326 & 439,240 & 431,481 \\
\hline Philippines & 92,074 & 79,993 & 85,030 & 87,936 & 77,206 & 87,944 & 101,539 & 105,130 & 99,698 & 136,978 & 139,217 \\
\hline Singapore & 166,179 & 184,160 & 204,494 & 205,449 & 194,523 & 241,334 & 307,180 & 327,253 & 364,733 & 376,235 & 393,037 \\
\hline Thailand & 93,568 & 95,643 & 90,069 & 84,586 & 78,405 & 92,949 & 102,902 & 97,712 & 104,138 & 104,812 & 124,409 \\
\hline USA & 390,929 & 394,802 & 397,965 & 441,546 & 369,258 & 395,729 & 412,617 & 411,416 & 414,060 & 458,691 & 479,452 \\
\hline \multicolumn{12}{|l|}{ Outbound } \\
\hline China & - & - & - & 168,427 & $1,518,501$ & $2,424,242$ & $2,846,572$ & $3,139,055$ & $3,109,145$ & $3,267,238$ & $3,403,920$ \\
\hline HK_MC & $3,970,849$ & $4,225,549$ & $4,227,081$ & $3,777,763$ & $3,036,066$ & $2,976,543$ & $2,744,393$ & $2,548,262$ & $2,576,333$ & $2,511,317$ & $2,535,297$ \\
\hline Indonesia & 185,348 & 186,165 & 201,358 & 186,117 & 171,278 & 179,845 & 212,826 & 198,893 & 166,965 & 170,301 & 176,478 \\
\hline Japan & $1,180,406$ & $1,214,058$ & $1,280,853$ & $1,309,847$ & $1,129,928$ & $1,377,957$ & $1,136,394$ & $1,560,300$ & $2,353,274$ & $2,971,846$ & $3,797,879$ \\
\hline Korea & 368,206 & 396,705 & 457,095 & 363,122 & 395,965 & 406,290 & 423,266 & 532,729 & 516,978 & 626,694 & 500,100 \\
\hline Malaysia & 161,296 & 181,911 & 187,788 & 157,650 & 152,442 & 212,509 & 209,164 & 193,170 & 232,240 & 198,902 & 201,631 \\
\hline Philippines & 119,125 & 110,041 & 107,824 & 114,155 & 95,158 & 139,762 & 178,876 & 211,385 & 131,299 & 133,583 & 180,091 \\
\hline Singapore & 184,926 & 204,834 & 189,835 & 167,479 & 137,349 & 166,126 & 207,808 & 241,893 & 308,003 & 283,925 & 318,516 \\
\hline Thailand & 268,231 & 379,275 & 353,439 & 332,997 & 258,973 & 350,074 & 382,635 & 306,746 & 498,748 & 419,133 & 599,523 \\
\hline USA & 578,998 & 593,794 & 587,872 & 515,590 & 414,805 & 436,233 & 404,848 & 469,568 & 385,169 & 425,138 & 477,156 \\
\hline
\end{tabular}

\subsection{Research methodology}

Through a series of statistical procedures, including descriptive statistics, correlation analysis, K-means clustering, 1-way MANOVA, and MDS (multidimensional scaling), this study explores the central and dispersion tendency of analyzed data, calculates correlation coefficients between variables, assigns each record into proper cluster by calculating the distances to every clusters, testifies the heterogeneous means exists for different clusters, and reduces dimension from high to 2 for better observation and interpretation, respectively.

\section{Empirical finding}

\subsection{Correlation analysis}

Correlation analysis examines the strength of association between two variables by calculating their correlation coefficient. The Pearson correlation is the most commonly used parametric method among all variations for this analysis (Larry et al., 2012). Limited by pages' restriction, only one correlation tables is illustrated here, yet this study will summaries the valuable results in conclusion section. Table 8 describes the correlation coefficients between markets calculated by monthly RBMT from 2005 to 2015.

TABLE VIII: Correlation coefficients between markets on monthly RBMT 2005 to 2015.

\begin{tabular}{|c|c|c|c|c|c|c|c|c|c|}
\hline Market & China & HK_MC & Indonesia & Japan & Korea & Malaysia & Philippines & "Singapore & Thailand \\
\hline$\overline{\mathrm{HK} \_\mathrm{MC}}$ & $.393^{*}$ & & & & & & & & \\
\hline Indonesia & $.457 *$ & $.759^{*}$ & & & & & & & \\
\hline Japan & $-.327 *$ & $-.515^{*}$ & $-.360 *$ & & & & & & \\
\hline Korea & $.412 *$ & $.479 *$ & $.504 *$ & $-.305^{*}$ & & & & & \\
\hline Malaysia & $.357 *$ & $.620 *$ & $.729 *$ & -.065 & $.513 *$ & & & & \\
\hline Philippines & $.369 *$ & .045 & $.297 *$ & .034 & $.298 *$ & $.371 *$ & & & \\
\hline Singapore & .184 & $.261 *$ & $.496 *$ & $.282 *$ & $.281 *$ & $.662 *$ & $.644 *$ & & \\
\hline Thailand & -.146 & $-.314 *$ & -.133 & $.657 *$ & $-.220 *$ & .078 & $.258 *$ & $.447 *$ & \\
\hline USA & $.357 *$ & $.617 *$ & $.740 *$ & -.040 & $.417 *$ & $.788 *$ & $.440 *$ & $.745^{*}$ & .150 \\
\hline
\end{tabular}

\subsection{K-means clustering}

Being a family of multivariate techniques useful for analyzing cases based on their scores on a range of measured variables, clustering analysis identifies cases with a comparable pattern of responses that can be 
regarded, for the purposes of the analysis, as similar. The output of a successful cluster analysis would be a small number of highly homogeneous clusters that are substantially different to each other (Hair et al., 1998).

As a nonhierarchical algorithm, K-means clustering need to be determined the cluster number first and can be processed then. Cluster number is set to be 4 in this study, in other word, each monthly record in different markets is assigned into one and the only one of four clusters according to the shortest distance calculated from the inputted variables. Table 9 gives the cluster belonging based on 8 indicators mentioned above.

TABLE IX: Cluster belonging based on gender's ratios

\begin{tabular}{|c|c|c|c|c|c|c|c|c|c|c|c|c|}
\hline Year & Cluster & China & HK_MC & Indonesia & Japan & Korea & Malaysia & Philippines & Singapore & "Thailand & "USA & "Total \\
\hline \multirow[t]{3}{*}{2005} & 1 & & & 3 & 11 & & 6 & 6 & 6 & & 4 & 36 \\
\hline & 3 & & 12 & 9 & 1 & 12 & 6 & 6 & 5 & 12 & 8 & 71 \\
\hline & 4 & & & & & & & & 1 & & & 1 \\
\hline \multirow[t]{3}{*}{2006} & 1 & & & 1 & 11 & & 3 & 4 & 7 & & 2 & 28 \\
\hline & 3 & & 12 & 11 & 1 & 12 & 9 & 8 & 4 & 12 & 10 & 79 \\
\hline & 4 & & & & & & & & 1 & & & 1 \\
\hline \multirow[t]{3}{*}{2007} & 1 & & & 1 & 10 & 1 & 5 & 8 & 6 & & 4 & 35 \\
\hline & 3 & & 12 & 11 & 2 & 11 & 6 & 4 & 4 & 12 & 8 & 70 \\
\hline & 4 & & & & & & 1 & & 2 & & & 3 \\
\hline \multirow[t]{4}{*}{2008} & 1 & 4 & & 4 & 7 & 4 & 6 & 8 & 6 & & 3 & 42 \\
\hline & 2 & & & & & & & & & & 1 & 1 \\
\hline & 3 & & 12 & 8 & 5 & 8 & 4 & 4 & 4 & 12 & 8 & 65 \\
\hline & 4 & 2 & & & & & 2 & & 2 & & & 6 \\
\hline \multirow[t]{4}{*}{2009} & 1 & 4 & & 2 & 8 & & 6 & 8 & 5 & & 9 & 42 \\
\hline & 2 & & & & & & & & 1 & & & 1 \\
\hline & 3 & 8 & 12 & 10 & 4 & 12 & 4 & 4 & 3 & 12 & 3 & 72 \\
\hline & 4 & & & & & & 2 & & 3 & & & 5 \\
\hline \multirow[t]{4}{*}{2010} & 1 & 4 & & 4 & 5 & 1 & 4 & 6 & 5 & & 8 & 37 \\
\hline & 2 & & & & & & 1 & & 1 & & & 2 \\
\hline & 3 & 8 & 12 & 8 & 7 & 11 & 3 & 6 & 3 & 12 & 4 & 74 \\
\hline & 4 & & & & & & 4 & & 3 & & & 7 \\
\hline \multirow[t]{4}{*}{2011} & 1 & 4 & & 5 & 9 & 4 & 6 & & 8 & & 10 & 46 \\
\hline & 2 & & & & & & 2 & & 1 & & & 3 \\
\hline & 3 & 8 & 12 & 7 & 1 & 8 & 1 & 12 & 1 & 12 & 2 & 64 \\
\hline & 4 & & & & 2 & & 3 & & 2 & & & 7 \\
\hline \multirow[t]{4}{*}{2012} & 1 & 10 & & 6 & 10 & & 4 & & 6 & & 8 & 44 \\
\hline & 2 & & & & & & 2 & & 1 & & & 3 \\
\hline & 3 & 2 & 12 & 6 & 2 & 12 & 1 & 12 & 3 & 12 & 4 & 66 \\
\hline & 4 & & & & & & 5 & & 2 & & & 7 \\
\hline \multirow[t]{4}{*}{2013} & 1 & 12 & & 10 & 4 & 3 & 5 & 6 & 5 & & 12 & 57 \\
\hline & 2 & & & & & & 2 & & 1 & & & 3 \\
\hline & 3 & & 12 & 1 & 8 & 9 & 1 & 6 & 4 & 12 & & 53 \\
\hline & 4 & & & 1 & & & 4 & & 2 & & & 7 \\
\hline \multirow[t]{4}{*}{2014} & 1 & 9 & & 10 & & 9 & 3 & 11 & 5 & & 12 & 59 \\
\hline & 2 & & & & & & 2 & & 1 & & & 3 \\
\hline & 3 & & 12 & 1 & 12 & 3 & & 1 & 4 & 12 & & 45 \\
\hline & 4 & 3 & & 1 & & & 7 & & 2 & & & 13 \\
\hline \multirow[t]{4}{*}{2015} & 1 & 10 & 1 & 9 & & 9 & 5 & 6 & 7 & & 12 & 59 \\
\hline & 2 & & & & & 1 & 3 & & 1 & & & 5 \\
\hline & 3 & & 11 & 2 & 12 & & & 6 & 3 & 12 & & 46 \\
\hline & 4 & 2 & & 1 & & 2 & 4 & & 1 & & & 10 \\
\hline Total & & 90 & 132 & 132 & 132 & 132 & 132 & 132 & 132 & 132 & 132 & 1,278 \\
\hline
\end{tabular}

\subsection{MANOVA}

Regarded as an extension of the independent samples t-test, analysis of variance (ANOVA) compares means of more than two groups at a time. If more than one dependent variable among groups should be compared, in comparison to running a series of ANOVAs, it is more effective and robust to run only one MANOVA. Testing the homogeneity of group means for multiple dependent variables, the MANOVA hypothesizes that the error variance of the dependent variable is equal across groups. 
After clustering processes has been conducted, it is necessary to verify each cluster should have heterogeneous means. Since more than one dependent variable exist, 1-way MANOVAs therefore are processed to make clustering more reasonable and robust. Serious of 1-way MANOVAs, were excused in this study. While the significant indexes of Wilks' Lambdas is less than 0.05 overall, the Post Hoc comparison should be performed to discover which pairs of them are mutually different. Not only the Wilks' Lambdas for the multivariate test, but the 6 indicators except for MTOR and FTOR here, demonstrated significant. Caused by the same pages' restriction just as correlation part, the results of Post Hoc would not be shown here. Table 10 summaries the tests of between-subjects effects for the 8 indicators.

TABLE X: Tests of between-subjects effects for genders

\begin{tabular}{llrrrr}
\hline \hline Source & DV & Type III SS & df & MS & F \\
\hline Cluster & Male Tourists Inbound Ratio & .423 & 3 & .141 & 12.496 \\
& Female Tourists Inbound Ratio & .428 & 3 & .143 & 12.662 \\
& Male Tourists Outbound Ratio & .015 & 3 & .005 & .000 \\
& Female Tourists Outbound Ratio & .015 & 3 & .005 & .000 \\
& Ratio of Balance Male Tourists & 396.974 & 3 & 132.325 & 1143.176 \\
& Ratio of Balance Female Tourists & 484.219 & 3 & 161.406 & 1527.245 \\
& Ratio of In-Out Male Tourists & 396.974 & 3 & 132.325 & 1143.176 \\
& Ratio of In-Out Female Tourists & 484.219 & 3 & 161.406 & .460 \\
& & & .000 \\
\end{tabular}

\subsection{MDS}

MDS is a set of data analysis techniques that display the structure of distance-like data as a geometrical picture. MDS transfers subject's distances in high dimension to a lower visible dimension for easy interpretation. The fitness measures of transformation contain S stress, stress, and RSQ. Experimental results show that the fitness measures mentioned are quite acceptable. Caused by the same pages' restriction just as correlation part, only few derived stimulus configurations of MDS are shown here. Figure 4 illustrates 4 stimulus graphs. While var1 to var10 representing China, HK_MC, Indonesia, Japan, Korea, Malaysia, Philippines, Singapore, Thailand, and USA, respectively, in (a), var1 to var12 figure 3 demonstrates stimulus graph in 10 years based on 7 age stratums. Figure 4 illustrates 6 stimulus graphs, including Japan, USA, HK, Malaysia, Singapore, and Macau, based on 8 indicators during 2005 to 2015 .

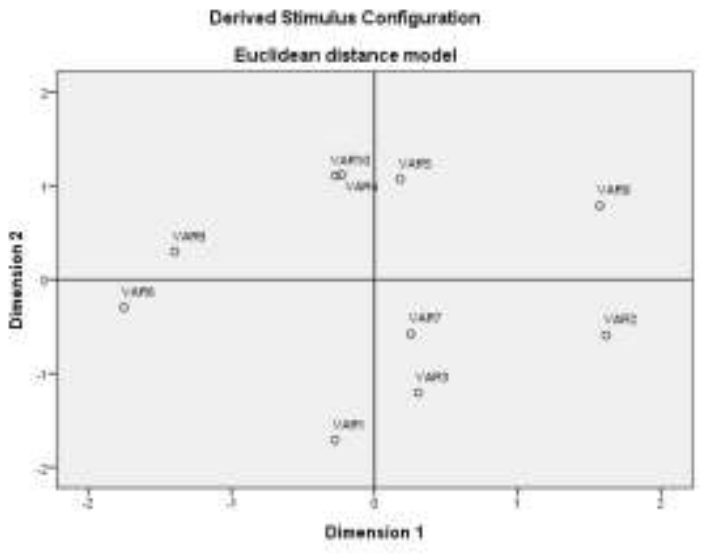

(a) 10 markets in 11 years

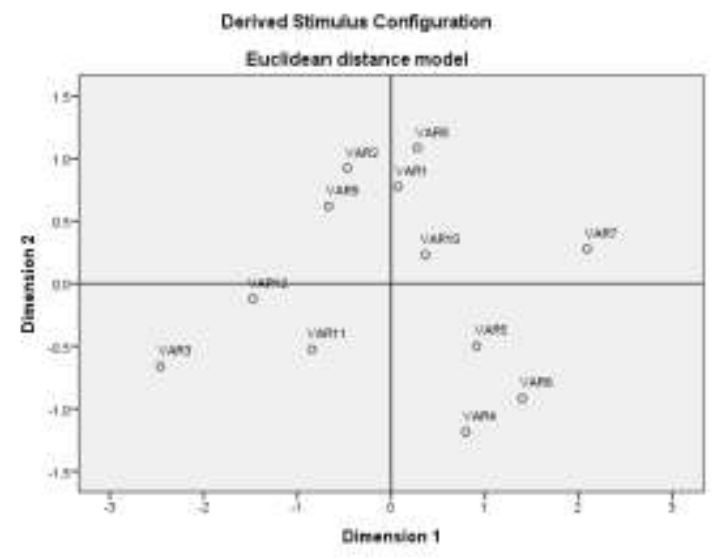

(b) 12 months in 11 years Japan 

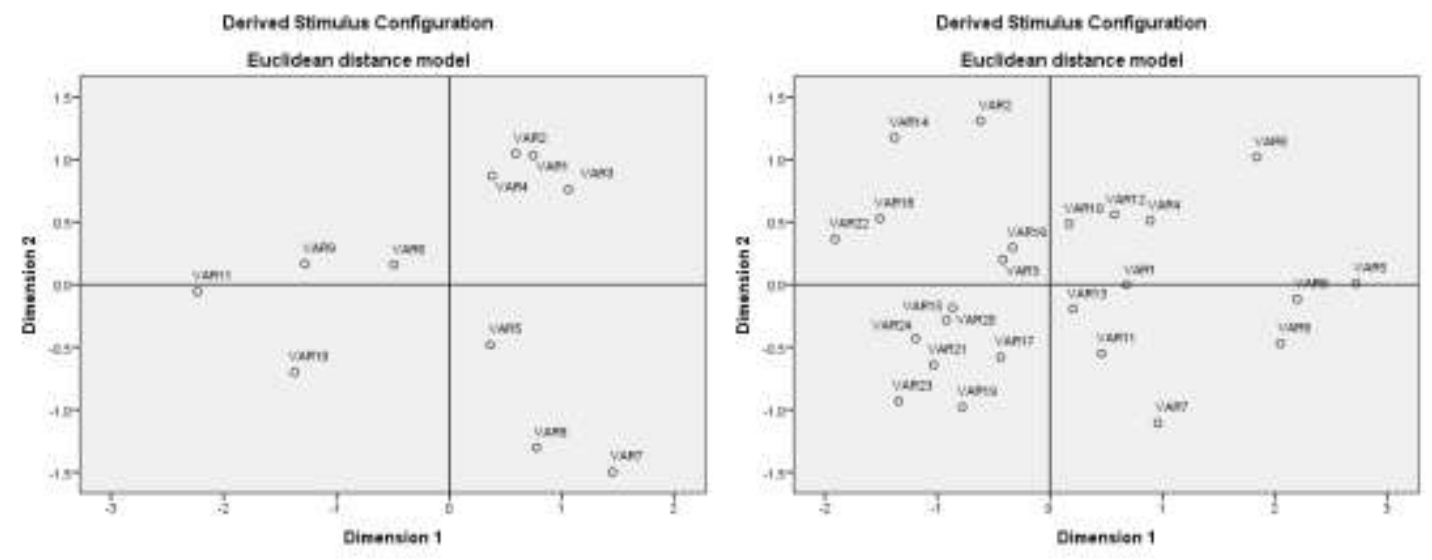

(c) July in 11 years Japan

(d) Last 24 Qs Japan(2010 2015)

Fig. 4: The derived stimulus configurations cross 11 years

\section{Discussion and conclusion}

Tourism has become a highly competitive business. The competitive advantage no longer relies on natural resources only, yet increasingly on the level of technology, information and innovation offered (Burger, Dohnal, Kathrada \& Law, 2001). Traditionally, tourism demand can be normally measured either by tourist arrivals at a destination, and tourists' expenditure while visiting, or nights stayed. Therefore, an accurate forecasting of tourist arrivals is helpful for planning for potential tourism demand to invest in tourism related facilities and improve tourism infrastructure (Chen et al., 2010).

The developing of tourism industry in Taiwan, since from 1948, can be segmented into 4 periods according to Tourism Bureau, M.O.T.C. Republic of China. These 4 periods including initial, leading-in, growing and mature period as well, can be described as follow (http//admin.taiwan.net.tw).

\section{(1) Initial period (1948-1959)}

Caused by retreating from Mainland in the civil war and migrating to Taiwan lately at the end 1940, the Taiwan government carried a strictly security protection in maintaining the stability of politics, economics, and society. Particularly owing to the constitutional-level ban, regarded as Temporary Provisions Effective During the Period of National Mobilization for Suppression of the Communist Rebellion, was implemented 1948, the protectionism lastingly impacted not only in politics and military affairs, but in tourism as well. Since 1948, issued through grants, loans, technological cooperation and selling or giving American agricultural products under Public Law 480, Taiwan was helped from US. And tourism is one of the benefitted industries among all technical supporting plans.

\section{(2) Leading-in period (1960-1978)}

In company with awareness of leisure getting more and more important to public, the government untied restrained ban gradually. The openings in this stage included the traveling agency can be applied and run by the local people, the tourism developing committee was founded, the encouraged-investment of international tourist hotel was legislated, the national park, national scenic areas, and forest parks were consecutively established.

\section{(3) Growing period (1979 1996)}

Taiwan revoked the ban of prohibiting citizen abroad traveling for sightseeing reason in 1979. Accompanying with significant economic growth, Taiwan experienced sustained growth in outbound visitors since then. Following by political unban allowing citizens to visit with their relatives in Mainland China under humanism thinking, the growth is prompted even higher than before. The awareness of appropriate leisure needed for humanity was getting rigid gradually.

\section{(4) Mature period (1997-)}


On account of appropriate leisure was popularly expected, Taiwan started leading-in two-day weekend since 1998 partially, and done fulfilling in 2001 successfully. Since then, the developing of tourism industry kept on prospering due to pursuing the balance of working and leisure among people in Taiwan.

Experiencing the prohibiting policy for citizen outbound tourism lifted in 1979, and ban of relative-visiting to mainland removed in 1987, the international outbound tourists have risen dramatically in Taiwan. Based on the official data offered by Tourism Bureau, M.O.T.C., Republic of China, monthly visitors with different genders from and destined to 10 main inbound and outbound markets, including Japan, Hong Kong(with Macau), Mainland China, Korea, U.S.A, Singapore, Thailand, Philippines, Indonesia, and Malaysia, as well, from 2005 to 2015 have been collected and analyzed to demonstrate and explore the static and dynamic patterns behind these historical records.

Differing from the tourism demand forecasting wildly studied by researchers, this paper aimed to explore the spatiotemporal patterns implicitly behind historical records. Correlation analysis clarifies the correlative relation among each different researched target. By time-freezing and time-slicing, this study successfully extracts out the static weights of different genders in each market, and traces the dynamic variations of observed objectives mentioned above. Records with similar patterns, or equivalently closer distances, are classified into same group in K-mean clustering process. Objects in the same cluster should inherit similar patterns, with distance closer, or even more competitive in attracting Taiwanese visitors. MANOVAs further confirm such clustering to be reasonable and effective by hypothesis-testifying the heterogeneous cluster centers. Lastly, MDSs successfully make the mutual distances and relative positions from high-dimension into a 2-dimensional visible and interpretable space. Thus, MDSs grant us the capability of observing, as time goes by, the changing or evolution with respect to the same objective.

\section{References}

[1] Burger, C. J. S. C., Dohnal, M., Kathrada, M., Law, R. (2001). A practitioners guide to time-series methods for tourism demand forecasting - a case study of Durban, South Africa. Tourism Management, 22, 403-409.

[2] Chan, Y. M. (1993). Forecasting tourism: A sin wav time series regression approach. Journal of Travel Research, 32, 58-60.

[3] Chandra, S., \& Menezes, D. (2001). Applications of multivariate analysis in international tourism research: The marketing strategy perspective of NTOs. Journal of Economic and Social Research, 3(1), 77-98.

[4] Chen, K. Y., \& Wang, C. H. (2007). Support vector regression with genetic algorithms in forecasting tourism demand. Tourism Management, 28, 215-226.

[5] Chen, M. H., Ying, L. C., \& Pan, M. C. (2010). Forecasting tourist arrivals by using the adaptive network-based fuzzy inference system. Expert Systems with Applications, 37, 1185-1191.

[6] Cho, V. (2003). A comparison of three different approaches to tourist arrival forecasting. Tourism Management, 24, 323-330.

[7] Chu, F.L (2008). Analyzing and forecasting tourism demand with ARRA algorithm. Tourism Management, 29, 1185-1196.

[8] Chu, F. L. (1998). Forecasting tourist arrivals: A combined approach. Tourism Management, 19(6), 515-520.

[9] Crouch, G.I., Schultz, L., \& Valerio, P. (1992). Marketing international tourism to Australia: A regression analysis. Tourism Management, 13, 196-208.

[10] Goh, C., \& Law, R. (2002). Modeling and forecasting tourism demand for arrivals with stochastic nonstationary seasonality and intervention. Tourism Management, 23, 499-510.

[11] Hair, J., W. Black, B. Babin, R. Anderson and Tatham (1998), Multivariate Data Analysis, Upper Saddle River, NJ: Prentice-Hall.

[12] Hernandez-Lopez, M., \& Caceres-Hernandez, J. J. (2007). Forecasting tourists' characteristics by genetic algorithm with a transition matrix. Tourism Management, 28, 290-297.

[13] Hernandez-Lopez, M. (2004). Future tourists' characteristics and decisions: The use of genetic algorithms as a forecasting method. Tourism Economics, 10(3), 245-262.

[14] Hiemstra, S. J., \& Wong, K. F. (2002). Factor affecting demand for tourism in Hong Kong. Journal of Travel and Tourism Marketing, 12(1-2), 43-62. 
[15] Hsu, C. I., \& Wen, Y. U. (1998). Improved grey prediction models for trans-pacific air passenger market. Transportation Planning and Technology, 22, 87-107.

[16] Hurley, S., Moutinho, L., \& Witt, S. F. (1998). Genetic algorithms for tourism marketing. Annals of Tourism Research, 25(2), 498-514.

[17] Kulendran, N., \& Witt, S. F. (2001). Cointegration versus least squares regression. Annals of Tourism Research, 29(2), 291-311.

[18] Larry D., Alison G., \& Neelu S. (2012). Handbook of research methods in tourism. Edward Elgar Publishing Limited.

[19] Law, R. (2000). Back-propagation learning in improving the accuracy of neural network-based tourism demand forecasting. Tourism Management, 21, 331-340.

[20] Law, R. \& Au, N. (1999). A neural network model to forecast Japanese demand for travel to Hong Kong. Tourism Management, 20, 89-97.

[21] Lim, C., \& McAleer, M. (2000). Time series forecasts of international travel demand for Australia. Tourism Management, 23, 389-396.

[22] Smeral, E., Witt, S. F., \& Witt, C. A. (1992). Econometric forecasts:Tourism trends to 2000. Annals of Tourism Research, 19(3), 450-466.

[23] Song, H \& Witt, S. F. (2010). Estimating the size of Chinese outbound travel market: A demand-size approach. Tourism Management, 31, 250-259.

[24] Song, H., \& Witt, S.F. (2000). Tourism demand modeling and forecasting: modern econometric approaches. Oxford: Pergamon.

[25] Song, H., \& Witt, S. F. (2006). Forecasting international tourist flow to Macau. Tourism Management, $27,214-224$.

[26] UNWTO. (2016). UNWTO Tourism Highlights 2016 Edition. UNWTO e-library.

[27] Wang, C. H. (2004). Predicting tourism demand using fuzzy time series and hybrid grey theory. Tourism Management, 25, 367-374.

[28] Wang, C. H., \& Hsu, L. C. (2008). Constructing and applying an improved fuzzy time series model: Taking the tourism industry for example. Expert Systems with Applications, 34(4), 2732-2738.

[29] Witt, S. F., \& Martin, C. (1987). Econometric models for forecasting international tourism demand. Journal of Travel Research, 25(3), 23-30.

[30] Wong, K. K. F., Song, H., \& Chon, K. S. (2006). Bayesian models for tourism demand forecasting. Tourism Management, 27, 773-780. 